\title{
A ILHA ASSOMBRADA: REALIDADES E ILUSÕES
}

\section{Rafael Victorino Devos}

Orientação Ana Luiza Carvalho da Rocha e Cornelia Eckert
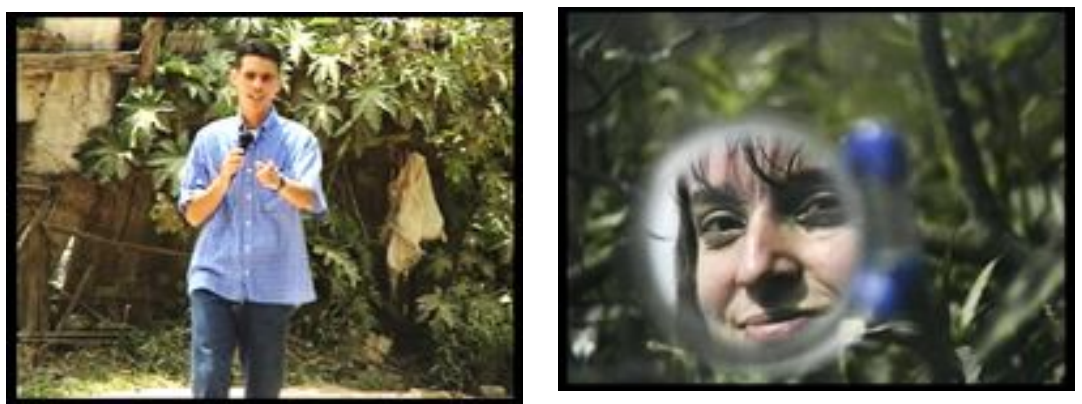

Ilha Assombrada-realidade ou ilusões?”

Oficina de vídeo da Illha dos Marinheiros, 2000

Como forma de enriquecer a discussão e explicitar tantas problemáticas, trago agora para esse trabalho uma experiência com documentário etnográfico. O documentário “Ilha Assombrada - realidade ou ilusões?" é fruto de uma oficina experimental de vídeo-documentário realizada com adolescentes moradores da Ilha Grande dos Marinheiros, periferia de Porto Alegre. As situações vividas durante a oficina trouxeram à tona muitas das questões colocadas até agora, na medida em que nós, professores, precisávamos trabalhar conceitualmente as dificuldades surgidas no processo de realização do documentário. Já os alunos, viveram na prática a trajetória do documentário, mostrada nos capítulos anteriores.

A oficina foi realizada de maio de 1999 a janeiro de 2000, ministrada por mim e por Alfredo Barros (estudante de Jornalismo e bolsista voluntário do NAVISUAL ${ }^{1}$ ), sob a orientação da Antropóloga Ana Luiza Carvalho da Rocha ${ }^{2}$. Participou ainda Silvia Cavichioli, também estudante de Jornalismo, registrando as aulas e as gravações como imagens adicionais e making-of.

A turma, inicialmente composta por 7 alunos, realizou um documentário em

1 Núcleo de Antropologia Visual, pertencente ao Laboratório de Antropologia Social, Programa de Pós-Graduação em Antropologia Social UFRGS.

2 Antropóloga pesquisadora junto ao Laboratório de Antropologia Social - PPGAS - UFRGS e orientadora do presente trabalho 
vídeo sobre histórias de assombrações, bruxas, lobisomens e outros causos fantásticos que são relatados por muitos moradores da Ilha dos Marinheiros. As aulas constituíram-se no acompanhamento das etapas necessárias para a realização do vídeo, instrumentalizando os alunos de acordo com as demandas de cada etapa.

A oficina origina-se de um projeto de especialização meu e de Alfredo Barros, com o objetivo (ingênuo?) de iniciar profissionalmente pessoas de classe popular na atividade de produção de vídeo, a fim de descobrir novas apropriações da linguagem audiovisual. $\mathrm{O}$ projeto teve o apoio do Banco de Imagens e Efeitos Visuais (no qual trabalho), núcleo de pesquisa pertencente ao Programa de PósGraduação em Antropologia Social da Universidade Federal do Rio Grande do Sul, que trabalha com pesquisa etnográfica e produção de documentários em Porto Alegre. Nesse sentido, somou-se o objetivo de pesquisa da tradição oral e da memória coletiva das ilhas de Porto Alegre. A intriga dessa oficina problematiza justamente a pesquisa, a produção do vídeo e a formação dos alunos. Um encontro dos objetivos dos professores com os sonhos, desejos e necessidades desses alunos. Ser documentarista e professor, nessa situação, implicou realizar uma exploração, uma etnografia visual a partir de um duplo ponto de vista. Conheceu-se um pouco da Ilha dos Marinheiros por duas vias: pelo nosso estranhamento e pela interpretação das próprias interpretações que realizam os alunos ao estranharem um lugar que, a princípio, lhes é familiar.

\section{Descobrindo Histórias}

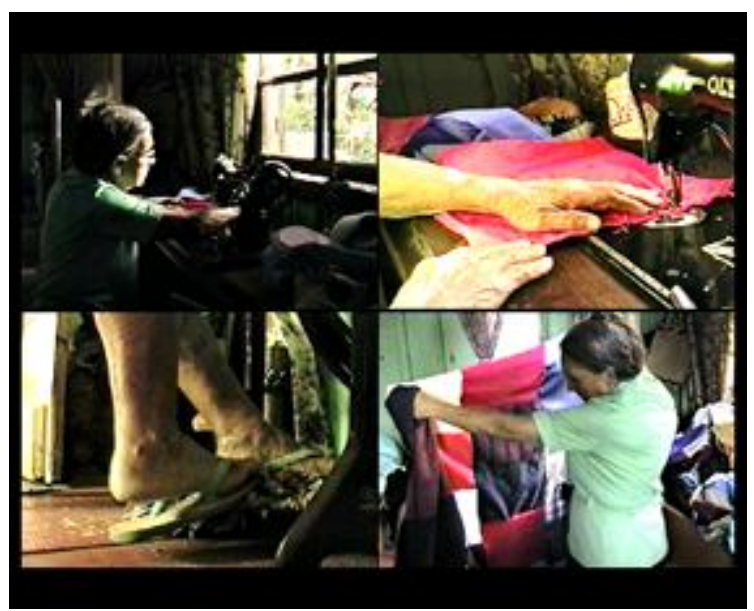

“Ilha Assombrada-realidade ou ilusões?”, Oficina de vídeo da Illha dos Marinheiros, 2000 
As primeiras aulas foram realizadas para familiarizar os alunos com a operação de equipamentos e principalmente, para definir um tema e um pré-roteiro para o nosso "filme". Sugerimos as histórias fantásticas por sabermos que seria um forte tema a ser explorado, que motivaria os alunos durante o processo, já que, para contar a nossa história, teríamos de ouvir muitas histórias, pesquisar. Os alunos aprovaram a idéia e partiram para a brincadeira de "detetive". Fizeram um levamento de histórias, narradores e locações para as gravações.

$\mathrm{Na}$ aula em que apresentaram sua "pesquisa", havia um tom de deboche com as histórias dos moradores mais velhos sobre noivas de branco, ruídos estranhos, fantasmas e bruxas. Mas, ao mesmo tempo, ficaram espantados com a quantidade de "causos" que se apresentavam na ilha. Ricardo fez um texto, quase uma reportagem, sobre a quantidade de histórias que levantara, muitas, contadas por sua vó. A seriedade de Ricardo com as histórias, ao contrário dos demais alunos, apontava para um respeito com algo que ele não acreditava muito, mas que dizia respeito a ele mesmo, já que sua vó falava de muitas aparições de seu avô, já morto. Nosso interesse de professores por essas histórias fez com que os alunos percebessem que, no fundo, aquelas histórias eram algo que lhes pertencia. Escolhemos as histórias mais fantásticas e recorrentes, definindo alguns informantes, preparamos os alunos para a gravação das entrevistas.

A escolha do tema foi fundamental para o processo de transposição de aprendizados em etnografia para os alunos. Semelhante ao trabalho da CTI com o projeto "Vídeo nas Aldeias", a proposta de fazer os alunos voltarem-se para sua comunidade, para encontrarem uma história para contar, fez com que questões de identidade e pertencimento a tal comunidade fossem tocados. Os alunos, acostumados a enfrentar diariamente o estigma que assombra as camadas populares dos grandes centros urbanos, passaram, então, a questionar-se sobre riquezas culturais pertencentes a tal comunidade. O olhar dos alunos, sobre a sua "subcultura" apontava para um novo olhar sobre si próprios.

A equipe foi definida com funções fixas para que se pudesse treinar cada um dos alunos em sua função. Posteriormente, pretendia-se trocar essas funções e aproveitar o aprendizado de cada aluno para transpô-lo no auxílio ao colega. Ricardo, de 18 anos, ficou como o câmera oficial da equipe junto a Greice, de 15 anos, com o 
monitor auxiliando-o na composição do plano, ambos sob a supervisão de Alfredo, ministrante da oficina. Cíntia, também de 15 anos, colocou-se como entrevistadora, sendo que Ana Luiza fez as primeiras entrevistas, a fim de trabalhar com Cíntia e o resto da equipe as primeiras noções de técnica de entrevista. Jairo, de 14 anos, responsabilizou-se pela produção do documentário e direção da equipe. Pamela, de 15 anos, ficou como assistente de produção e Débora, 16 anos, ficou com a captação de som direto. Esses três ficaram sob minha supervisão. Há ainda Wilmar, que, inicialmente, seria assistente de câmera, mas acabou abandonando a oficina logo nas primeiras aulas. Ao acompanhar o funcionamento dessa equipe de gravação, precisávamos, enquanto professores, sistematizar o nosso próprio processo de trabalho. Isto implicou resgatar outras experiências com a produção de documentários e com toda uma tradição cinematográfica, apresentada nos capítulos anteriores desse trabalho. Essa tradição passava a encontrar-se com outras tradições narrativas na Ilha Grande dos Marinheiros.

A primeira entrevista foi feita com Laci, uma antiga moradora da ilha, de aproximadamente 70 anos. Laci contou-nos a sua história de vida, como foi parar na Ilha dos Marinheiros e como era a ilha antigamente. Contou que é mãe de 12 filhos, que é viúva e que, atualmente, costura para sobreviver e para doar roupas para as pessoas da vila. Falou da vez em que foi atropelada na ponte que corta a vila e do tesouro que podia ter encontrado na ilha, caso entregasse a vida de um filho (que acabou morrendo mesmo), segundo um padre lhe disse em sonho. As primeiras histórias fantásticas foram contadas por Laci, de tesouros de antigos estancieiros enterrados na Ilha, de assombrações e aparições, enquanto eu podia perceber nos alunos não tanto o interesse pela história, mas pela situação de gravação em si. Ricardo estava concentrado em sua tarefa e parecia fascinado pela visão de Laci no visor da câmera; Jairo e Débora revezavam-se ouvindo a voz de Laci nos fones; Cíntia prestava mais atenção na equipe de gravação do que na entrevistada. Encerrada a entrevista, pedi à Laci para gravá-la trabalhando. Laci assumiu seu personagem, contente, em frente à sua antiga máquina de costura. Alfredo dava dicas à Ricardo de composição do plano: as mãos de Laci, muito enrugadas, passando o tecido pela agulha da máquina de costura; os pés de Laci pedalando na máquina; retalhos de roupas dispostos sobre uma mesa; o rosto de Laci concentrada. Os demais 
alunos olhavam no monitor, ou simplesmente observavam a cena. Laci mostrava um dos muitos acolchoados que costurava para dar aos vizinhos. Estava ali uma personagem surgindo, sendo construída por ações. Uma moradora da vila, como os alunos, sendo descoberta. Será que os alunos percebiam?

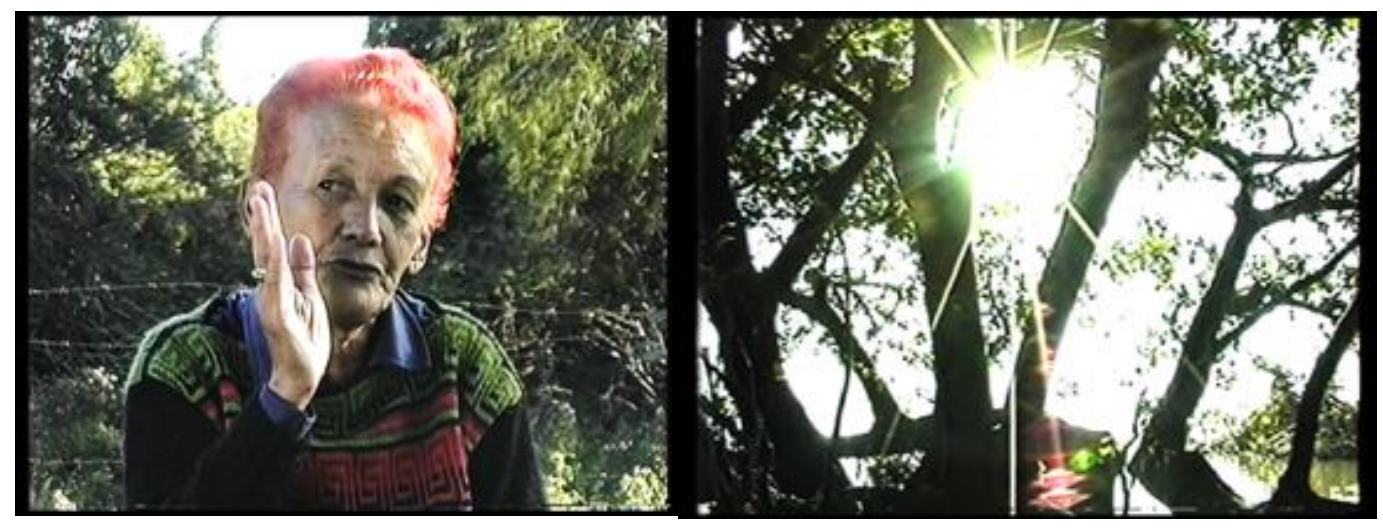

"Ilha Assombrada -realidade ou ilusões?"

Oficina de vídeo da Illha dos Marinheiros, 2000

Fizemos outra entrevista com Maria, ex-moradora da Ilha dos Marinheiros, morando agora na Ilha das Flores. Maria tornou-se a grande narradora da história, junto com Laci. Sentada sob uma árvore Maria contou-nos um pouco da sua vida. Viúva, mãe de 10 filhos, só dois estão vivos atualmente. A filha mora no interior e o filho está preso em São Paulo. Aos 70 anos, mora com o neto. Maria é benzedeira. Benze as pessoas que vão procurá-la em sua casa. Reza todo dia com a Bíblia aberta nas mãos, sem saber ler. Maria nos contava sua vida e muitas histórias de lobisomem (ela já viu um), da filha que perdeu embruxada ("a bruxa chupa todo o sangue da criança"), das vozes que lhe chamam. Eu me emocionava com a sabedoria de vida, com a fé de Maria, com sua força ao enfrentar tantas dificuldades e sua capacidade de narrar essas histórias, com tremenda força dramática. Cíntia, Pamela e Débora dessa vez estavam bem interessadas na entrevista, fazendo tantas perguntas quanto Ana Luiza. Jairo segurava o rebatedor e também fazia perguntas. Só Greice e Wilmar, que apareceu aquele dia, estavam mais concentrados em ver a entrevista pelo monitor do que fazer perguntas. Ricardo recebeu um desafio. Pedi-lhe que trabalhasse com o plano bem fechado num momento mais forte da entrevista. Maria se movia contando das benzeduras e da filha que morrera embruxada. Ricardo a seguia lentamente com a câmera. Segundo ele, "tomou um cansaço". 
Uma entrevista que não "rendeu", realizou-se com Neuza, aproximadamente 30 anos de idade. Neuza não possuía a mesma densidade de Laci, ou melhor, ela não se revelou uma grande personagem na entrevista. Fora algumas histórias de aparições em sua casa, de um homem semelhante a Jesus Cristo pedindo ajuda à sua porta, Neuza não nos relatou muitas histórias, foi lacônica em muitas respostas e sua grande fala era: "Não tenho muito a dizer sobre essas histórias, quem sabe são os velhos." O que "rendeu" nessa gravação foram as imagens que fizemos da beira do rio, onde Ricardo pode fazer, com a câmera na mão, alguns planos mais livres. E o que ele enquadrava era o sol refletido na água, água dourada batendo nos aguapés e na areia da margem, segundo ele, o nosso "tesouro enterrado". Débora descobria as possibilidades do microfone, apontando para as árvores e os pássaros, para a ponte dos carros, para o chão com folhas pisadas. Jairo apontava coisas a filmar.

Após a entrevista com Neuza, no mesmo dia, ainda fizemos algumas imagens da vila, da passagem sob a ponte onde as pessoas atravessam para os dois lados da Ilha dos Marinheiros. Muitas carroças passavam, um bom dado sobre a principal atividade econômica dos moradores da vila: separação de lixo. Pessoas passavam caminhando embaixo da ponte, enquanto ônibus, carros, caminhões, passavam por cima, fazendo um barulho infernal. Mais próximo da beira, um homem levava seu cavalo para beber água. Algumas crianças jogavam bolita. No rio, passavam lanchas velozes e barcos a motor. A equipe parecia empolgada pela gravação de tantos gestos cotidianos. Eu via um cotidiano presente que parecia despercebido dos alunos: o lixo. A vila onde moram essas pessoas é puro lixo, atirado na calçada, pelo chão, pela grama, nos pátios das casas, por tudo. Em verdade, até o cheiro da vila é desagradável. Pelo menos, para mim. Os alunos pareciam não enxergar tanto lixo. Ao trocar as pilhas do monitor junto com Greice, Jairo não teve dúvida: largou as pilhas gastas junto com a embalagem no chão. Chamei a sua atenção para isso e ele juntou sem dar muita importância. Pedi para que colocasse numa lixeira. Jairo respondeu: que lixeira? A lixeira era o próprio chão.

A última entrevistada foi Juventina, a vó de Ricardo. Moradora antiga da Ilha, Juventina falou do tempo em que a ilha era só mato e ela morava no fundo da ilha, à beira do rio, rio acima. Falou do marido que fazia carroças, com quem se casou com 14 anos de idade. Juventina contou algumas histórias de lobisomens, bruxas, tesouros 
e aparições, no entanto, sem a mesma capacidade narrativa de Laci e Maria. Balançando-se na cadeira, no quintal da casa de Ricardo, falava com um sorriso matreiro, como quem sabe muito mais do que aquilo que quer contar. Ricardo puxava por algumas histórias que já ouvira da avó, mas ela não contava.

Após tantas gravações, os alunos comentavam os rumos que estava tomando o documentário, ainda numa fase de descoberta de histórias e personagens. Os alunos achavam que as pessoas estavam falando demais. Em verdade, só o que os alunos

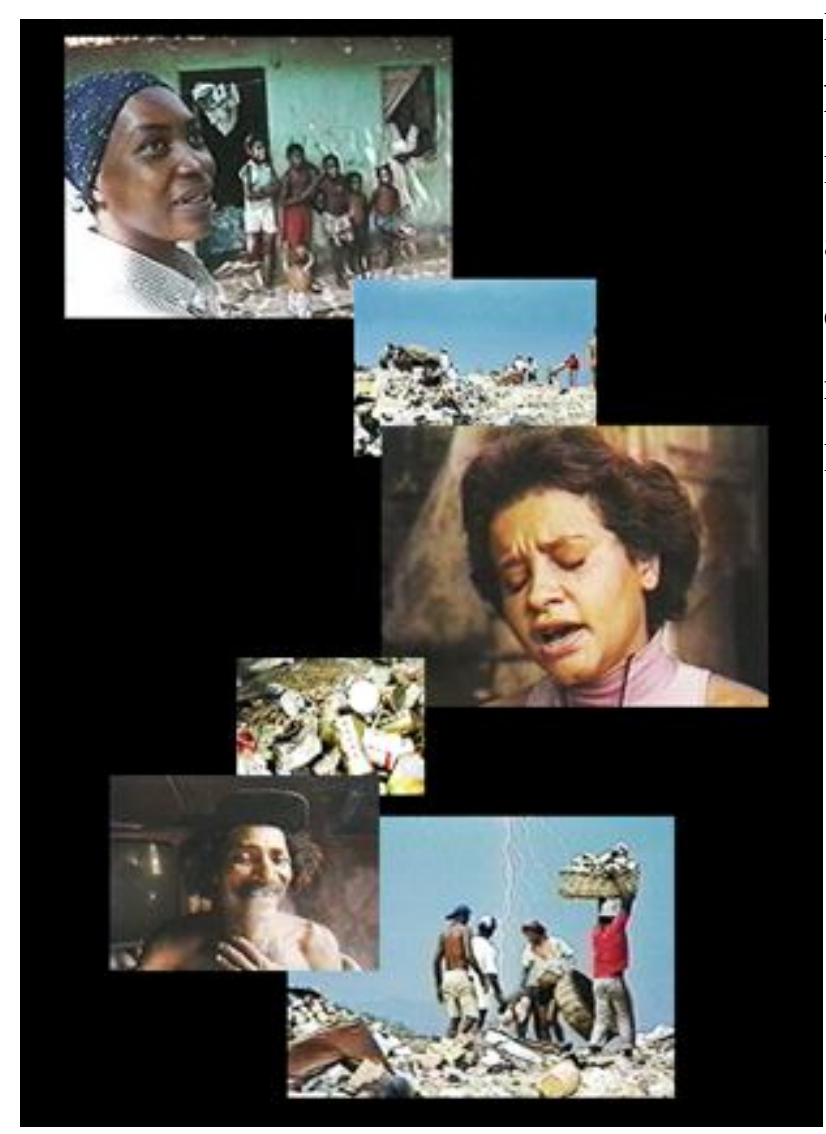

"Ilha Assombrada-realidade ou ilusões?"

Oficina de vídeo da Illha dos Marinheiros, 2000 levavam em conta eram as histórias de tesouros, lobisomens, bruxas e aparições. A história de vida das pessoas e suas vivências na Ilha dos Marinheiros não lhes interessavam.

$\mathrm{Na}$ aula seguinte, exibimos um trecho de um documentário para os alunos. Era o "Boca de Lixo” de Eduardo Coutinho, sobre pessoas que trabalham e vivem em um lixão no Rio de Janeiro.

Na seqüência escolhida era com uma das pessoas do lixão mostrando sua casa e seus familiares para a equipe de gravação. A filha dessa moradora dizia que queria ser cantora. Coutinho pede a ela que cante e ela vive o seu momento de sucesso, cantando para a televisão. Na montagem, ao som do canto da menina, vemos imagens do cotidiano da casa da personagem até que voltamos a ver imagens do lixão. É uma seqüência emocionante, que deixou os alunos da oficina vidrados. A partir dessa sequência, trabalhamos com os alunos a noção de personagem em 
documentário. Falando das pessoas que entrevistamos, colocamos a importância de apresentar um personagem no vídeo e construí-lo, através de gestos cotidianos, de sonhos, de depoimentos sobre a sua história. Retomando o pré-roteiro, falamos da importância de se apresentar o local onde se passa a história (a Ilha dos Marinheiros) e os personagens que participam dessa história (as mulheres entrevistadas).

\section{Observando as imagens falarem sobre si e sobre o mundo}

Aqui é possível perceber algumas questões que Jean Rouch introduziu no processo de realização de documentários, da capacidade das imagens de falarem tanto dos sujeitos retratados quanto dos produtores dessas imagens. Os alunos se viam incomodados nessas imagens de lixo, que, no fundo, era exatamente as imagens que primeiro apareciam do lugar em que vivem.

Desde o início da oficina aparecia a diferença entre as visões de mundo de adolescentes de uma periferia urbana ainda com traços de uma comunidade rural, em contraste com uma cultura de classe média intelectualizada de seus professores universitários. Os alunos demonstravam um desejo de se apropriar de estilos de vida mais ligados ao contexto urbano. Recuperar uma riqueza dramática na trajetória das personagens era apontar para grandes valores presentes em sua comunidade. Como fazia Prelorán, propunha-se que os alunos buscassem falar da Ilha dos Marinheiros, a partir de seu próprio universo simbólico, das histórias do lugar.

Conceitos do estudo de narrativas em Antropologia também passavam a ser trabalhados. A relação entre as narrativas de trajetória social e história de vida se confundiam, na entrevista, com as histórias fantásticas. Analisando as gravações, os alunos diferenciavam tais histórias e podiam agora perceber a força dramática de cada uma delas. E a memória social que aparecia nos relatos acabava sendo a memória dos alunos. Percebiam também a performance dessas narradoras, ao brincar com algumas expressões e gestos próprios de Maria, Laci e Juventina. Tão importantes quanto as histórias, eram as narradoras que aprenderam com a tradição oral, cada uma do seu jeito. 


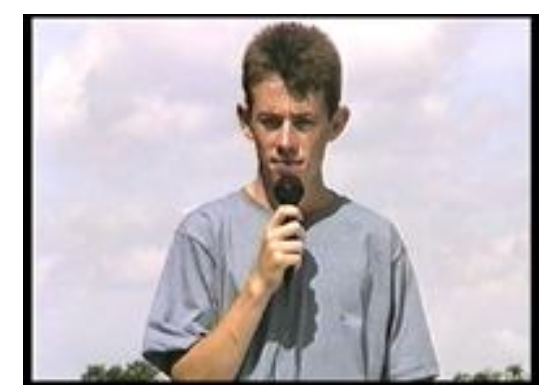

"Ilha Assombrada - realidade ou ilusões?"

Oficina de vídeo da Illha dos Marinheiros, 2000

\section{Caçando Fantasma}

$\mathrm{Na}$ aula seguinte falamos de linguagem cinematográfica. Enquadramentos, movimentos de câmera e lente, ângulos de câmera e, principalmente, noção de sequência, cena, plano e tomada. Os alunos precisavam expressar um ponto de vista que começava a surgir. Fazendo exercícios diretamente com a câmera, em sala de aula, os alunos, um a um, vivenciavam, na prática, conceitos como foco, enquadramento, plongée, corte, travelling. Redescobriam os recursos expressivos de uma linguagem que já conheciam do ponto de vista de espectadores de televisão.

Fizemos, então, um exercício de captação de imagens. Fomos para o interior da ilha, gravar a beira do rio, alguns barcos, uma casa abandonada. A cena das taquareiras foi uma das primeiras gravações com clara intenção narrativa. Com a história da noiva de branco que aparecia próximo a uma taquareira, que Juventina contou, gravamos uma taquareira no interior da ilha. Termos como zoom, pan, foco, começavam a ser escutados durante a gravação, assim como "mais de baixo", "caminhando", "mais escuro", "mais lento". Os alunos iam sugerindo planos a serem captados e, o mais importante, como seriam captados.

O tom realista das primeiras imagens começava a ser substituído por imagens “assustadoras”. É possível traçar um paralelo com Meliés, no sentido da deformação da imagem na busca de expressar um ponto subjetivo da realidade. E, graças à etnografia realizada, os alunos já se viam capazes de narrar com imagens. A busca de uma correlação, entre as imagens produzidas e as imagens que as histórias narradas despertavam, apontava para uma busca de correspondência estética entre os 
fenômenos estudados e a narrativa produzida. Histórias fantásticas não podiam ser retratadas por qualquer imagem da Ilha dos Marinheiros. Ao mesmo tempo, era de uma certa "atmosfera" do local que essas imagens precisavam surgir, pois era justamente à paisagem da ilha, aos cenários, que muitas assombrações estavam associadas.

Seguimos em frente com tal gravação, chegando a uma casa abandonada. Gravamos a casa escura, vazia, aludindo a uma presença humana: uma cadeira, um balanço, uma janela aberta. Mas a medida em que descobríamos esses lugares na ilha, mais parecida com um pic-nic a gravação ficava. Enquanto que eu acompanhei Ricardo com o monitor na mão, Jairo olhava alguns lugares para gravar. O resto da equipe catava frutas nas árvores, corria gritando de um lado para o outro, enlouquecia. A gravação acabou por ali. Retornamos para a vila e tivemos uma conversa sobre a postura nas gravações. A partir dali, a equipe começava a fragmentar-se.

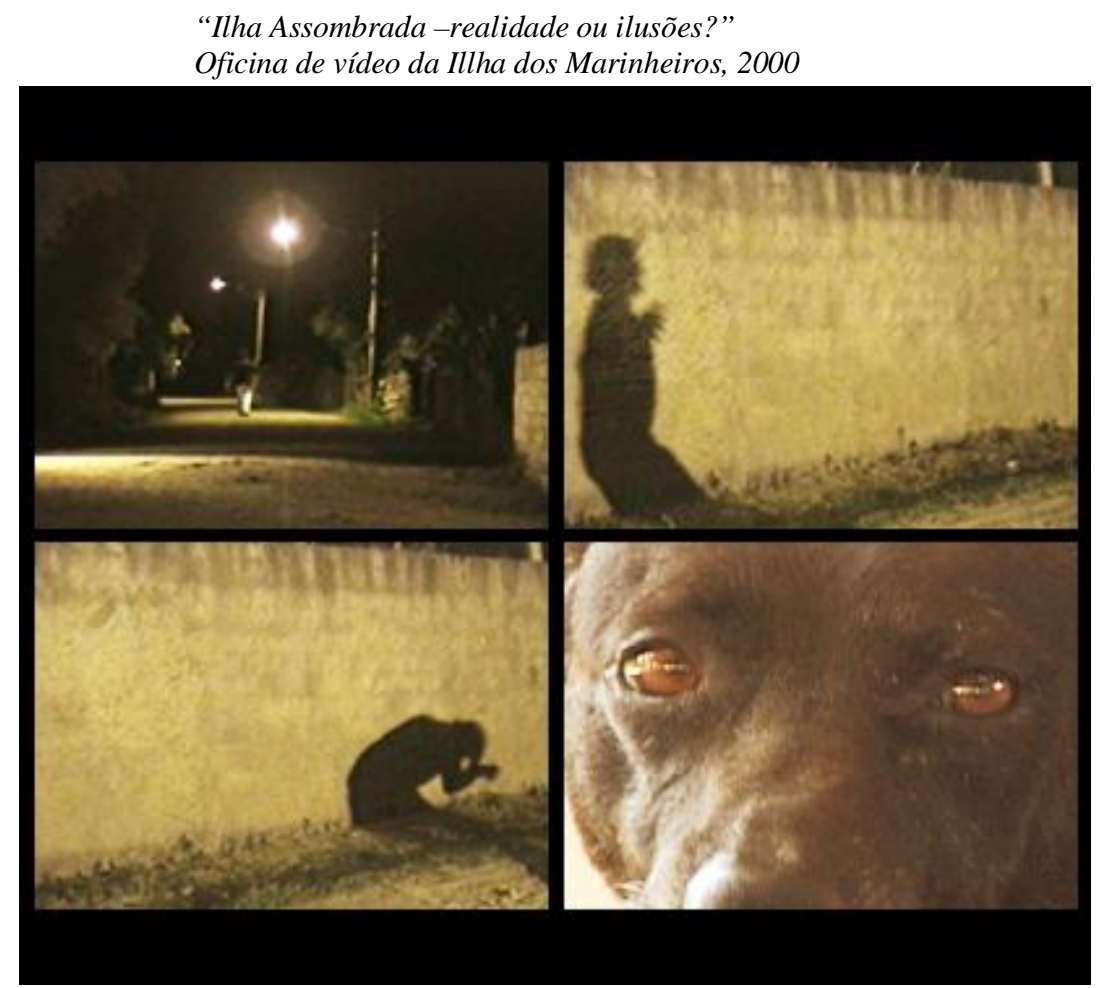

Novas dificuldades surgiam. Trabalhar com adolescentes de classe popular era competir, não apenas com os momentos de lazer dos alunos, mas com o seu cotidiano de classe popular (cuidar dos irmãos, limpar a casa, dificuldades com a 
escola) e suas expectivas. Pensar as aulas significou ver os alunos com os limites (e a capacidade de superá-los) que sua comunidade determinava, muito diferentes das condições de adolescência em camadas médias, às quais pertencem seus professores. Não bastava dar a câmera ao "nativo", convertê-lo em "cineasta" significava dar-lhe outro lugar em seu meio, constituí-lo como diferente.

$\mathrm{Na}$ aula seguinte, já não contando com a participação de Cíntia, Pamela e Greice, fizemos um cronograma para a gravação de imagens importantes para o documentário. No dia combinado, apareceu a turma quase completa. Além de divertidas imagens de perseguições num pântano, de pontos de vista de lobisomens e lugares sombrios, gravamos uma reza de Dona Maria, do jeito que ela havia narrado na entrevista, levando flores e velas para a estátua de Nossa Senhora Aparecida, num pequeno santuário à beira do rio. Caminhamos acompanhando a nossa personagem, com muitas crianças e curiosos em volta. À frente da santa, Maria e uma vizinha rezavam concentradas, fazendo um pedido pelas crianças da vila. Ricardo fechava o plano nos rostos, nas mãos, no rosto da santa, nas velas, nas flores. A instabilidade da câmera, contra o sol, acabou somando-se à dramaticidade da cena. Mais uma vez eu me emocionava com a cena e, mais uma vez, perguntava-me se eles percebiam a beleza daquele momento, ou se apenas o encaravam como um gesto cotidiano daquela personagem rezadeira.

As aulas seguintes foram destinadas a trabalhar o roteiro do documentário. Tendo assistido a algumas imagens e trechos de entrevistas, pedimos aos alunos que tentassem separar por sequências a história, pensando em início, meio e fim. A turma já se encontrava reduzida, formada por cinco integrantes, depois, quatro e finalmente, três alunos: Jairo, Ricardo e Débora. Elaboramos uma estrutura de roteiro, uma escaleta, prevendo a ordenação das histórias narradas.

Estruturar o roteiro significou, quanto às imagens, perceber se as mesmas estavam de acordo com as histórias contadas. Algumas "encaixavam" perfeitamente, já para outras histórias, era necessário gravar mais. Por isso, após a definição do roteiro, houve um grande salto nas gravações, no domínio da linguagem. Nesse momento, os alunos tinham absoluta clareza da intenção narrativa de cada imagem. Foram ficcionalizações de desenterro de tesouros, transformação do lobisomem, sombras noturnas, passos de vultos brancos, corridas pelo mato, perseguições. 
Chegamos a desenhar os planos a serem rodados, detalhando o que seria gravado, pensando o ângulo da câmera, a duração do plano, os movimentos, o enquadramento, os objetos de cena necessários.

Chamo a atenção para algumas sequências que, segundo alunos e professores, são as mais fortes, dramaticamente, do documentário. Há a seqüência de travellings nas taquareiras, até chegar em planos sombrios da casa abandonada causa o primeiro estranhamento do vídeo, após as banais imagens iniciais que apresentam a ilha. Esse primeiro "susto" é introduzido com um veloz travelling rasteiro no cemitério, até chegar a uma antiga lápide, já corroída pela ação do tempo. A instabilidade do travelling, o borrão da imagem (o obturador da câmera foi ajustado para borrar a imagem quando a câmera se movia rapidamente) e o ângulo rasteiro fazem a correspondência do cemitério com uma possível origem das assombrações: a presença de um outro cemitério, onde hoje é a comunidade.

Para os alunos, já era mais importante do que escolher o que gravar, pensar como gravar. A seqüência da transformação do lobisomem deixa isso bem claro. Como filmar um lobisomem? A sugestão de Jairo, que de início virou piada, acabou dando a idéia: gravar um cachorro, dos bem feios. Foi assim que surgia a montagem do vulto humano (eu) andando na rua, que vemos se retorcer todo (Alfredo) na sua sombra num muro até se encolher no chão. Em seguida, os olhos e o focinho de um cão em primeiríssimo plano, mostravam a tragédia de nosso personagem. A instabilidade da câmera e a iluminação noturna contribuíram para o ritmo da montagem. Ao assistir à transformação, Maria, que contou a história mais assustadora de lobisomem, confirmou com um sorriso surpreso e satisfeito efeito da cena: deu medo.

A arte, a performance do contador de histórias surtia efeito nos alunos (e nos professores). A arte do narrador de fazer ver, de aludir a imagens, paisagens, atmosferas e personagens imaginários ajudou a equipe a expressar semelhantes imagens mentais na linguagem cinematográfica. E se eram nos cantos da ilha que os fantasmas e lobisomens apareciam, era lá mesmo, em cenários reais que precisávamos procurá-los. Um neorealismo fantástico.

Da mesma forma, toda a tradição de "filmes de terror", que os alunos já haviam assistido, além de outros discursos visuais como programas de telejornalismo 
sensacionalista deram o tom assustador dessas reconstituições. O banalismo de certas reconstituições televisivas foi evitado na medida em que havia uma correspondência entre a paisagem (natural e humana) da ilha com elementos estéticos das histórias e com a estética que une as imagens produzidas. As imagens não ilustram os depoimentos, criam uma tensão e narram também, através da imagem em movimento, as histórias.

\section{Autores e heróis}

"Os antigo dizem que é, que é sete filha mulher, quando a mãe ganha sete filha mulher, então a última sai bruxa. E diz sete filho homem sai lobisomem. Assim os antigo dizem, não sei." Laci Fontes Rolim, aproximadamente 70 anos.

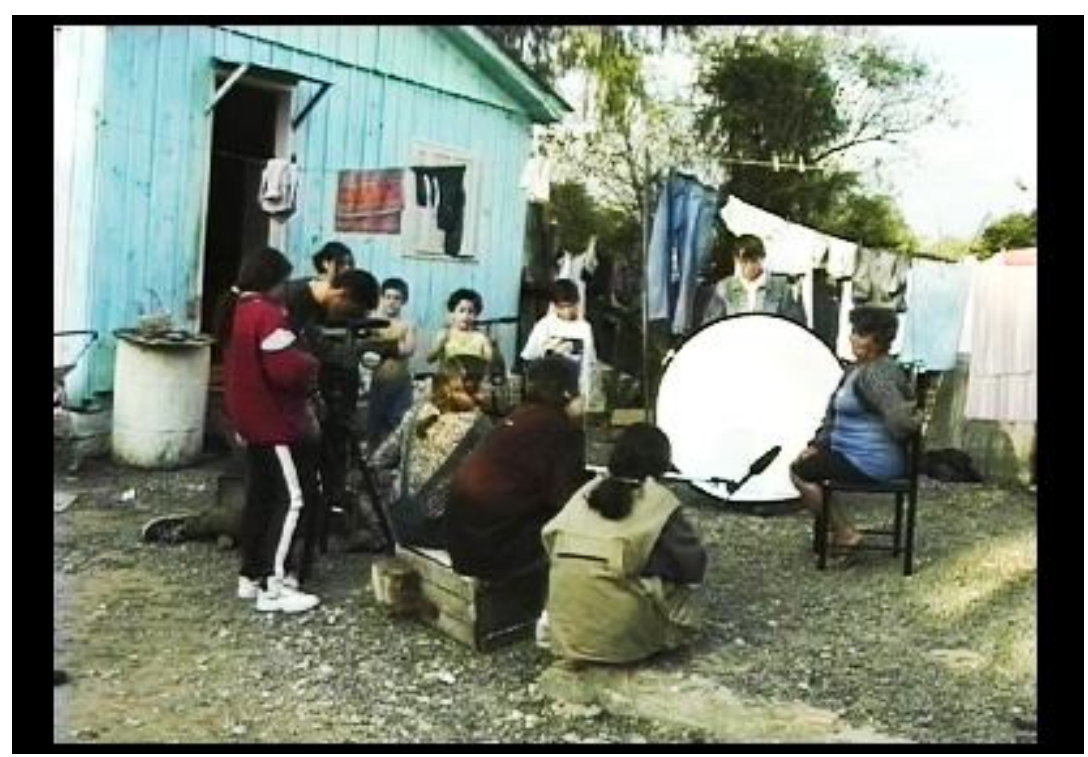

("Ilha Assombrada-realidade ou ilusões?" Oficina de vídeo da Illha dos Marinheiros, 2000)

Voltemos ao momento da elaboração do roteiro final do documentário. Foi nesse momento em que pensamos com os alunos a montagem da história, articulando as diferentes narrativas (aparições, lobisomens, bruxas, história pessoal dos personagens) com as imagens produzidas e a serem produzidas. Essas imagens incluíam as imagens de making-of que Silvia Cavichioli gravara. Verem-se nas imagens, após quatro, cinco meses de oficina, causou um estranhamento nos alunos. Como usar aquelas imagens? Mostrar a equipe de gravação era muito mais do que desconstruir o processo de produção, era dar um ponto de vista bem específico para a câmera. Era colocar o lugar dos alunos e professores nessa história. 
As imagens da equipe gravando apontavam justamente para o processo de trabalho da oficina: a desistência de alguns colegas, o crescimento na capacidade narrativa das imagens pelos que permaneceram, um primeiro espanto com os equipamentos nas primeiras aulas e uma intimidade com os mesmos posteriormente. Uma imagem significativa: os alunos assistindo às imagens gravadas. Jairo comentou do processo de análise das entrevistas, do domínio sobre as histórias contadas. Os alunos, e também nós professores, percebíamos que aquelas imagens de making of explicitavam o processo interpretativo. $\mathrm{O}$ olhar que mudou era justamente a interpretação do fenômeno estudado.

Os alunos percebiam que também eram narradores das histórias, já que interpretaram o que ouviram e gravaram imagens a partir dessas interpretações. Fazendo o roteiro, interpretavam novamente, não só as histórias, como as imagens. Resultado: se viram como parte da história, aquilo tudo falava muito deles. Nesse momento ficou clara a transformação dos alunos, de nativos para narradores, sujeitos do processo cinematográfico. Usar as imagens que Silvia gravara deles mesmos era como usar as imagens das moradoras. Precisaram pensar em si mesmos como personagens ${ }^{3}$.

Nesse sentido, a auto-reflexividade do documentário aparece de uma maneira diferente. A questão da interpretação é fundamental. Geertz, na via de uma antropologia interpretativa, pensa a cultura enquanto "teia de significados", e o antropólogo, enquanto alguém que "lê" a cultura do outro a partir da leitura do outro sobre sua própria cultura. Não temos acesso aos fenômemos em si, mas a maneira como os sujeitos os vivenciam, interpretando-os. Assim, as moradoras da Ilha Grande dos Marinheiros, nas entrevistas, estavam interpretando suas histórias pessoais e o seu encontro com essa tradição oral, no ato de narrar e lembrar de histórias que ouviram e que narraram. A equipe de gravação, interpretava essas narrativas nas imagens gravadas e, novamente, interpretava a própria experiência vivida. O espectador tece também a sua interpretação, ao ser jogado dentro da experiência de ouvir histórias e olhar a paisagem, os cenários. E partilha da

3 penso aqui nas idéias de Mikhail Bakhtin, sobre a relação do autor e do herói: "De acordo com uma relação simples, o autor deve situar-se fora de si mesmo, viver a si mesmo num plano diferente daquele em que vivemos efetivamente a nossa vida; essa é a condição expressa para que ele possa completar-se até formar um todo, graças a valores que são trascendentes à sua vida, vivida intensamente, e que lhe asseguram o acabamento. Ele deve tornar-se outro relativamente a si mesmo, ver-se pelos olhos de outro.” BAKHTIN, M. Estética da Criação Verbal. São Paulo: Martins Fontes, 1992, p.35. 
descoberta do tesouro, junto com a equipe: a riqueza das histórias, da sua descoberta.

O diálogo com o espectador é ainda mais explicitado com as "vinhetas" entre as sequências, em que os alunos apresentam o que está por vir. Nesse momento, eles assumem o lugar de narrador, eles tomam a palavra, em primeira pessoa, e brincam com as possíveis interpretações de quem os assiste (você aí, acredita?).

Falamos de uma concordância entre a estética das imagens mentais das histórias fantásticas e a estética das imagens técnicas produzidas em vídeo. Da mesma forma há algo de comum entre os diferentes narradores da história. Podemos dizer que nós (alunos e professores) aprendemos, com a tradição oral, a sermos narradores. Assim como Maria, Juventina e Laci articulavam tempo e narrativa na sua fala, fizemos o mesmo com o documentário. Paul Ricouer", em "Tempo e Narrativa", fala de uma inteligência narrativa que acomoda e expressa o tempo através do círculo hermenêutico da tríplice mimese. A primeira mimese é a "précompreensão do mundo e da ação". As moradoras sabem que histórias são boas de ser contadas, que experiências que viveram que dão uma boa história. Se sabem isso, é porque a percepção, a acomodação e a interpretação da experiência vivida se dá pelo processo de simbolização. A segunda mimese é a tessitura da intriga, o ordenamento lógico e dramático dos acontecimentos, simbolicamente, a fim de "assustar" o ouvinte, prender sua atenção, mexer com sua imaginação. Implica em ordenar e modelar cada ação que é contada. Por fim, a terceira mimese fala do diálogo com o ouvinte, com o leitor. Mimese I e II se dão em função de mimese III. Há uma tradição de contar histórias, um jeito de contar que permite que o ouvinte saiba do que o narrador está falando, e permite inclusive que o leitor reconheça uma boa história e se entregue a ela.

E por que contamos e ouvimos histórias? Benjamin, lamentando o desaparecimento da figura do narrador na sociedade moderna, aponta para a troca de experiências como constitutiva do processo narrativo:

“o narrador entra na categoria dos professores e dos sábios. Ele dá conselhos - não como o provérbio: para alguns casos - mas como o sábio: para muitos. Pois lhe é dado recorrer a toda uma vida. (Uma vida, aliás, que abarca não só a própria experiência, mas também a dos outros.

4 RICOUER, Paul. Tempo e Narrativa. Tomo I. Campinas, SP: Papirus, 1994. 
Àquilo que é mais próprio do narrador acrescenta-se também o que ele aprendeu ouvindo.) Seu talento consiste em saber narrar sua vida; sua dignidade, em narrá-la inteira. O narrador é o homem que poderia deixar a mecha de sua vida consumir-se integralmente no fogo brando de sua narrativa." 5

A vida ensina. Contar uma história é tentar fazer com que o efeito que a experiência vivida causou no narrador seja o efeito da história no ouvinte. Por um momento, narrador e ouvinte dividem o mesmo horizonte. E cada história fica como que depositada em seu ouvinte. Um tesouro, que precisa ser passado adiante. Assim, ouvintes aprendem com narradores, e se tornam narradores. Esse aprendizado, essa troca de diferentes técnicas e tradições narrativas foi o grande "tesouro" que encontramos na Ilha Grande dos Marinheiros.

É claro que a oficina e o documentário ainda possuem muitas limitações. Nesse sentido, ao avaliar o processo, percebemos que o nosso objetivo primeiro, de iniciar profissionalmente os alunos, não foi plenamente atingido. Os alunos realmente aprenderam a realizar um documentário, mas isso não fez deles documentaristas, já que os meios de produção de tal atividade não são acessíveis à sua condição econômica. No entanto, a finalização do documentário e sua exibição para a comunidade consolidou um processo de formação de sujeitos. A partir da oficina, os alunos repensaram seu lugar no mundo, redescobrindo o lugar de onde vêm e situando-se no contexto de Porto Alegre, sendo autores de uma história, sujeitos que têmalgo a dizer ao mundo sobre o seu canto de mundo.

\section{Referências}

AUMONT, Jacques. A Estética do Filme. Campinas, SP: Papirus, 1994.

BAKHTIN, Mikahil. Estética da Criação Verbal. São Paulo: Martins Fontes, 1992.

BARNOUW, Erik. El Documental, História y estilo. Barcelona, Espanha: Gedisa, 1996.

BENJAMIN, Walter. O Narrador in Os pensadores. São Paulo: Abril Cultural, 1980.

BECKER, Howard. Balinese Character: uma análise fotográfica. In Cadernos de Antropologia e Imagem, $\mathrm{n}^{\circ}$ 2, Antropologia e Fotografia. Rio de Janeiro: UERJ, NAI, 1996. pgs. 137-145.

MACDOUGALL, David. De quem é essa história? in Cadernos de Antropologia e Imagem, $\mathrm{n}^{\circ} 5$, Antropologia e Mídia. Rio de Janeiro: UERJ, NAI, 1997. pgs. 93-107.

CINEMAIS, revista de cinema e outras questões audiovisuais. $\mathrm{N}^{\circ} 8$. Rio de Janeiro: Editorial CINEMAIS, 1997.

COLOMBRES, Adolfo. Cine, Antropologia y Colonialismo. Buenos Aires, ARG: Ediciones del Sol, 1991.

GALLOIS, D. e CARELI, Vincent. Vídeo e diálogo Cultural - Experiência do Projeto Vídeo nas Aldeias, in ECKERT, C. e GODOLPHIM, N. (orgs) Revista Horizontes Antropológicos, n², PPGAS/

5 BENJAMIN, Walter. Os pensadores. São Paulo: Abril Cultural, 1980, p. 74. 
UFRGS, 1995 , p.49-57.

GEERTZ, Clifford. A Interpretação das Culturas. Rio de Janeiro: LTC, 1989.

GINSBURG, Faye. Não necessariamente o filme etnográfico: traçando um futuro para a antropologia visual. in ECKERT, Cornelia e MONTE-MÓR, Patrícia (orgs.) Imagem em foco: novas perspectivas em antropologia. Porto Alegre: Editora da Universidade/UFRGS, 1999. pgs. 31-55.

MACHADO, Arlindo. Pré-cinemas \& pós-cinemas. Campinas, SP: Papirus, 1997.

MALINOWSKI, Bronislaw. Argonautas do Pacífico Ocidental in Os Pensadores. São Paulo: Abril Cultural , 1976.

MARTIN, Marcel. A Linguagem Cinematográfica. São Paulo: Brasiliense, 1990.

RICOUER, Paul. Tempo e Narrativa, Tomo I. Campinas, SP: Papirus, 1994.

HOBSBAWM, Eric. Era dos Extremos - O Breve Século XX. São Paulo: Companhia das Letras, 1996.

ROCHA, Ana Luiza Carvalho da. Antropologia das Formas Sensíveis; entre o visível e o invisível, a floração de símbolos”. In: ECKERT, C. e GODOLPHIM, N. (orgs.) Horizontes Antropológicos, Antropologia Visual, n², PPGA/UFRGS, 1995.

ROCHA, Ana Luiza Carvalho da. Antropologia Visual, um convite à exploração de encruzilhadas conceituais. in ECKERT, Cornelia e MONTE-MÓR, Patrícia (orgs.) Imagem em foco: novas perspectivas em antropologia. Porto Alegre: Editora da Universidade/UFRGS, 1999. Pgs. 55-85.

RUBY, Jay. The Image Mirrored: reflexivity and the documentary film ROSENTHAL, Alan (org.). New Challenges for Documentary. University of Califórnia, EUA: 1998. Pgs 64-77.

SAMAIN, Etienne. Ver e dizer na tradição etnográfica: Bronislaw Malinowski e a fotografia. In ECKERT, Cornelia e GODOLPHIm, Nuno (orgs.) Revista Horizontes Antropológicos, ${ }^{\circ}$ 2, Antropologia Visual. Porto Alegre: PPGAS - UFRGS, 1995.

SARAMAGO, José. Ensaio Sobre a Cegueira. São Paulo: Companhia das Letras, 1995.

WINKIN, Yves. A Nova Comunicação - da teoria ao trabalho de campo. Campinas, SP: Papirus, 1998.

WINSTON, Briam. Documentary: I think we are in trouble. in ROSENTHAL, Alan (org.). New Challenges for Documentary. University of Califórnia, EUA: 1998. Pgs 21-33. 